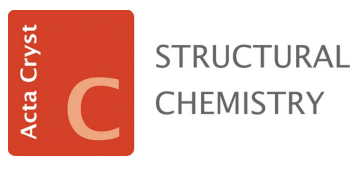

ISSN 2053-2296

Keywords: book review; chemical nomenclature; crystal structure.

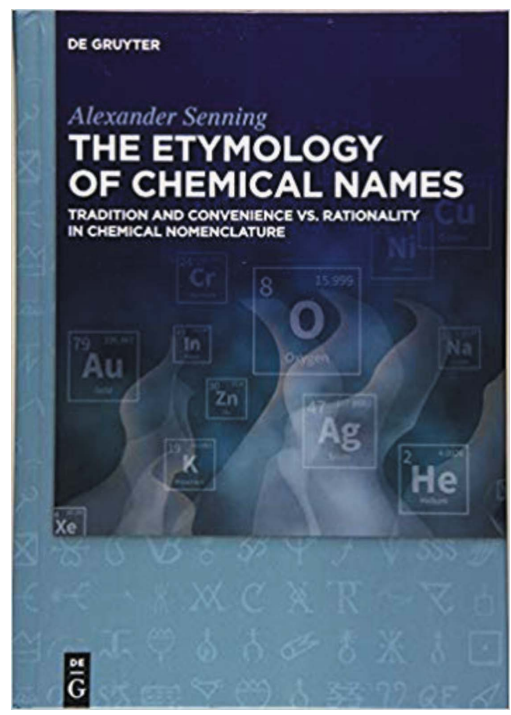

(C) 2020 International Union of Crystallography

\section{The Etymology of Chemical Names. Tradition and Convenience vs. Rationality in Chemical Nomenclature. By Alexander Senning. De Gruyter, 2019. Hardcover, Pp. xiv+505. Price EUR 149.95, USD 172.99, GBP 136.50. ISBN 978-3-11-061106-9.}

\author{
Marc Hebrant*
}

Université de Lorraine, CNRS, LCMPE, Nancy, France. *Correspondence e-mail: marc.hebrant@univ-lorraine.fr

The first five of the 20 chapters of this book focus on the sometime logical pathway that is followed to name a compound, trivial names based on a feature of the compound, the results of early attempts at nomenclature, the International Union of Pure and Applied Chemistry (IUPAC) and the Chemical Abstracts Service (CAS).

Chapter 6 is devoted to the naming of the elements.

Chapters 7 to 11 are given over to the etymologies of large classes of natural compounds (terpernes, carbohydrates, amino acids and peptides, and others).

Chapter 12 is devoted to the named reactions, chapter 13 to the naming of minerals, chapter 14 to nonproprietary drugs and excipients, and chapter 15 to the International Organization for Standardization (ISO) names of pesticides and agrochemicals.

Chapter 16 contains 25 pages of initialisms and acronyms, chapter 17 contains 25 pages of chemical terms and vocabulary, and chapter 18 is constituted of 18 pages of prefixes and suffixes.

Had the two short final chapters been written by a young researcher, they would have been named perspectives and future work, in this book they are Trivial chemical names with disputed etymology (chapter 19) and Some chemical names without known etymology (chapter 20).

What can be said about such a book? The very first idea that comes to the reader's mind is what an unbelievable amount of work these 500 pages represent! In the preface it is said that it is the fruit of more than half a century of university teaching and research, but this information does not allow one to imagine the density of this book. Indeed, etymology is a side product of the scientific activity of the author who has published more than 200 articles on sulfur compounds ('thio' from 'theion', literally the divine, p. 243), whereas this book could reasonably be the result of the entire career of a linguist.

In a second approach, starting to browse the book initially to find names that always intrigued him (Monensin after Streptomyces cinnamonensis, p. 41), the reader was caught up by the book and very soon started to read randomly the etymologies of names from place to place in the book. Thus began a strange journey that touched on history [Olympite $\mathrm{LiNa}_{5}\left(\mathrm{PO}_{4}\right)_{2}$ was named in honour of the 1980 Olympic games in Moscow, p. 392], language (olefin comes from the French gaz oléfian, oil-making gas, p. 158), geography [Minium $\left(\mathrm{HgS}\right.$ or $\left.\mathrm{Pb}_{3} \mathrm{O}_{4}\right)$ was named after the river Minus in Iberia, p. 386] and the early days of chemistry (carbinol is an obsolete name for methanol, p. 463).

Some of the names illustrate the great creativity of chemists, for instance (my favourite among the hundreds of entries I have read), King Kong peptide (p. 324), so called because this oligopeptide causes small crabs to abandon their usual submissive behaviour towards larger members of the species, to erect their head part and to curl their tails up like a scorpion. Everybody but a chemist would have named that peptide the 'very stupid crab peptide'!

For those aiming at using this book as a tool, for instance, teachers aiming at illustrating their lesson, i.e. more than for recreational purposes, it has to be said that it is not that practical; there is no alphabetical order to aid in finding a name. For instance, to find Monensin rapidly, the reader has a priori to know that this name originates from the source of this compound. This is really the weak point of the book. Such an amount of work deserves 50 pages more (or replacing the chapter on the named reactions which is 


\section{book reviews}

not that worthy) to give an alphabetical list of the names, indicating the pages on which they are treated. It even deserves an electronic edition with hyperlinks allowing multiple-criteria intuitive research within the data.

At least two other ideas come to the reader's mind:

- the importance of the chemical name to the knowledge of compounds. The excellent example of the compounds Salvarsan and Neosalvarsan (p. 165) initially described as arsenobenzene derivatives, which are still misrepresented in some publications (one more example that one free living encyclopaedia cannot be the only resource);
- the fact that a compound can be described by three equivalent but different IUPAC names perfectly illustrates the total impossibility of obtaining a simple, logical and univocal naming system in the field of chemistry. The millions of compounds that exist today, a number still growing, are the fruits of centuries of discoveries and this wealth of diversity together with the weight of history by themselves explain the difficulties in naming.

As a conclusion 'more than a half a century' of etymology does not solve the problem of naming the results of centuries of discoveries, but it helps! 